\title{
Effective safety propaganda: A study in South African industry
}

\author{
J. Fisher and R. Parry \\ Division of Industrial Psychology, University of the Witwatersrand, Johannesburg
}

In this study a safety propaganda programme was designed, introduced, monitored, and analysed in the context of ongoing industrial activity. Pre-experimental investigations revealed areas of unsafe activity which were then subjected to the experimental safety propaganda mate. rial. Results showed that in a number of workshops studied the propaganda had a positive effect in terms of a reduction in the number of unsafe incidents. Ancillary findings showed wide differences in the formal and informal attitudes expressed by both managerial and supervisory grades towards simple safety situations. It is suggested that such inconsistency is unlikely to be conducive to a stable behavioural commitment to safety procedures.

S. Afr. J. Bus. Mgmt. 1985, 16: $92-97$

In hierdie studie is 'n veiligheidspropagandaprogram ontwerp, voorgestel, gemonitor en geanaliseer in samehang met huidige industriële aktiwiteite. Vorige eksperimentele ondersoeke het areas van onveilige aktiwiteite onthul wat toe onderhewig gemaak is aan die eksperimentele veiligheidspropagandamateriaal. Resultate in 'n aantal werkwinkelstudies het bewys dat die propaganda 'n positiewe effek getoon het in terme van 'n vermindering van die aantal onveilige voonalle. Ondergeskikte bevindinge het 'n aantal verskille in die formele en informele houdings van beide bestuurs- en toesighoudende vlakke getoon ten opsigte van eenvoudige veiligheidsregulasies.

S.Afr. Tydskr. BedryfsI. 1985, 16: $92-97$
J. Fisher* and R. Parry

School of Ps! chology, University of the Witwatersrand, I Jan Smuts Avenue, Johannesburg, 2001 Republic of South Africa

-To whom correspondence should be addressed

\section{Introduction}

In South Africa the National Occupational Safety Association (NOSA) conservatively estimates the cost of industrial accidents to be at least R400 million each year, (NOSA, 1979). In human terms 17789 industrial injuries were reported to the Department of Manpower in 1982 and 16489 in 1983. This figure includes 493 people who were fatally injured in 1982 and 489 in 1983, (Department of Manpower, 1984).

Reduction in the severity and frequency of industrial accidents is clearly desirable in human, organizational, and financial terms.

One route for the reduction of unsafe actions which may lead to accidents is to promote awareness of alternative safe actions through safety propaganda.

Sell (1977) has provided a comprehensive review of the use of safety propaganda. He suggests that propaganda is:

- . . an attempt to change the attitudes and/or behaviour of people who are not specifically in a learning situation, and who do not expect or may not even be aware of the information or instructions being given to them'. (Sell, 1977: 203);

while safety propaganda is:

'. . . an organized attempt to change attitudes towards safety, and to cause people to act in a safe way, but excluding those situations where the target population is undergoing a period of formal instruction.' (Sell, 1977: 203).

The more common types of safety propaganada include posters, full length films, short-length films (e.g. television and cinema advertising), verbal propaganda (radio, loudspeakers, etc.), safety competitions, and other incentives and leaflets applicable to non-training situations.

Much of the important research into the use and effectiveness of safety propaganda is directed towards evaluating large-scale campaigns on issues such as road safety and fire prevention. In the case of large-scale television campaigns evaluation of possible behavioural changes is made difficult because of the lack of control over the exact proportion of the population exposed to the propaganda. Numbers of viewers exposed can never be established for certain.

However in more controlled, restricted circumstances such as industrial environments there is evidence to suggest that safety propaganda techniques can successfully lead to a decrease in unsafe acts, (Lander and Sell, 1960).

The use of safety propaganda in South African industry has not been widely researched. Apart from a study reported by Winter (1963), little formal evaluation has been published. Winter examined the understanding shown by black South 
African workers towards the content of a series of job-related safety posters. The low level of comprehension found could be attributable to such factors as the portrayal of behavioural variables through artistic conventions which were not a part of the subject sample's tradition.

Sell (1977) concludes that to be really effective safety propaganda must:

'1. Be specific to a task or situation.

2. Back up a training programme.

3. Give a positive instruction.

4. Be placed close to where the desired action is to take place.

5. Build on existing attitudes and knowledge.

6. Emphasise non safety aspects.'

(Sell, 1977: 213) and should not:

'1. Involve horror because in the present state of our knowledge this appears to bring in defence mechanisms in the people at whom the propaganda is most directed.

2. Be negative, because this can show the wrong way of acting when what is required is the correct way.

3. Be general, because almost all people think they act safely. This type of propaganda is thus seen as only relevant to other people.'

(Sell, 1977: 213)

In more general terms safety propaganda should be purposefully directed towards those who are seen to be at risk. Moreover, in the industrial context where the attitudes symbolized by the safety programme are different from those of management, safety propaganda will be of little value. Safety propaganda must cover topics over which workers have some control, and management support for the proposed action is necessary.

\section{Aims of the present study}

The effectiveness of the recommendations for the construction and use of safety propaganda proposed by Sell (1977) has not, as far as we are aware, been put to the test in the context of South African industry. The aim of the present study was to monitor and analyse a safety propaganda programme in the context of ongoing industrial activities, closely following the guidelines and recommendations set out by Sell (1977) for the use of effective safety propaganda.

\section{Procedure}

The study was conducted at a large electrical component manufacturing plant situated in the East Rand in the Transvaal. The organization comprised a labour-intensive structure with a mainly 'european' executive and supervisory management group controlling a 'non-european', semi-skilled, and unskilled labour force.

\section{Preliminary inspection}

A preliminary inspection of the plant was carried out over a four-week period in search of unsafe phenomena. Inspection was guided by an analysis of accident reports for the preceding six months.

These investigations revealed that a significant number of incidents occurred from three phenomena spread over five large workshops within the plant. The observed pattern is set out in Table 1. In order to preserve the anonimity of the participating company these workshops are identified by the letters ' $A$ ' to ' $E$ '.

Measurement of noise levels in workshops $A$ and $D$, where failure to wear ear muffs was felt to be a problem, revealed levels of $92-95 \mathrm{dBA}$ at riveting workstations in workshop $\mathrm{D}$, and $100-105 \mathrm{dBA}$ at sandblasting and fabricating work-
Table 1 Showing details of unsafe phenomena revealed from the pre-experimental investigation

\begin{tabular}{ll}
\hline Phenomenon & Workshop \\
\hline $\begin{array}{l}\text { Failure to provide and use goggles at grinder } \\
\text { workstations }\end{array}$ & A, B, C \\
$\begin{array}{ll}\text { Failure to use ear muffs at riveting and other } \\
\text { workstations }\end{array}$ & A, D \\
$\begin{array}{l}\text { Failure to use protective gloves at workstations } \\
\text { when welding, spot-welding and cutting metal }\end{array}$ & A, E \\
\hline
\end{tabular}

stations in workshop A. General workstations in workshop A were recorded at 90-95 dBA. All of these levels are well above the recommended and statutory levels for accoustic safety.

\section{Evaluating existing safety propaganda}

Safety propaganda during the preliminary period was sparse. It consisted of a small number of standard posters distributed by NOSA. These were often placed on notice boards, a NOSA recommendation, but not in strategic positions. Two examples of these posters are given in Figure 1.

The effectiveness of these two posters, in terms of being visual reminders to encourage safe behaviour, was established through informal interviews conducted with small groups of workers. As few of the shopfloor work-force were fluent in either English or Afrikaans an interpreter proved to be essential. These interviews revealed a minimum understanding of the posters, often leading to incorrect and humorously erroneous interpretations, as illustrated by the following quotations:

Respondent: Shopfloor worker. Target: Poster, Figure 1 (a). 'The goggles look like they can be used for swimming, but I don't know what the dog is doing there . . . What does the dog have to do with swimming?'

Respondent: Shopfloor worker. Target: Poster, Figure 1 (b). 'With all these things around that man's head it looks like he is going to protect himself in a battle . . . So it looks like he is a soldier in the army preparing himself for war.'

All NOSA posters carry, in very small print, six points on how to use the material effectively. These suggest inter alia: 'Explain the meaning of this poster to employees through 5 minute "safety tip talks".'

Although it could not be established whether the meaning of the two example posters had ever been explained to those workers interviewed, it should be apparent from the kind of response quoted above that as visual reminders this material is quite devoid of helpful association. The general nature of the poster in Figure 1 (b) is, as Sell (1977) suggests, of little value. Artwork was found to be confusing on both posters, and slogans were not understood by a work-force fluent in neither English nor Afrikaans. In view of the minimal understanding displayed no attempt was made to take accurate ratings of meaning for these posters.

\section{Evaluating managerial and supervisony disposition to safety}

During this preliminary period a questionnaire survey was conducted to assess the formal disposition of supervisors and executive and shopfloor managers towards safety in the workplace. The findings of this survey are set out in Table 2 and reveal a strong, positive commitment to safety issues, safety propaganda and the need to improve safety practices.

Such a finding is not surprising in view of the direct nature 

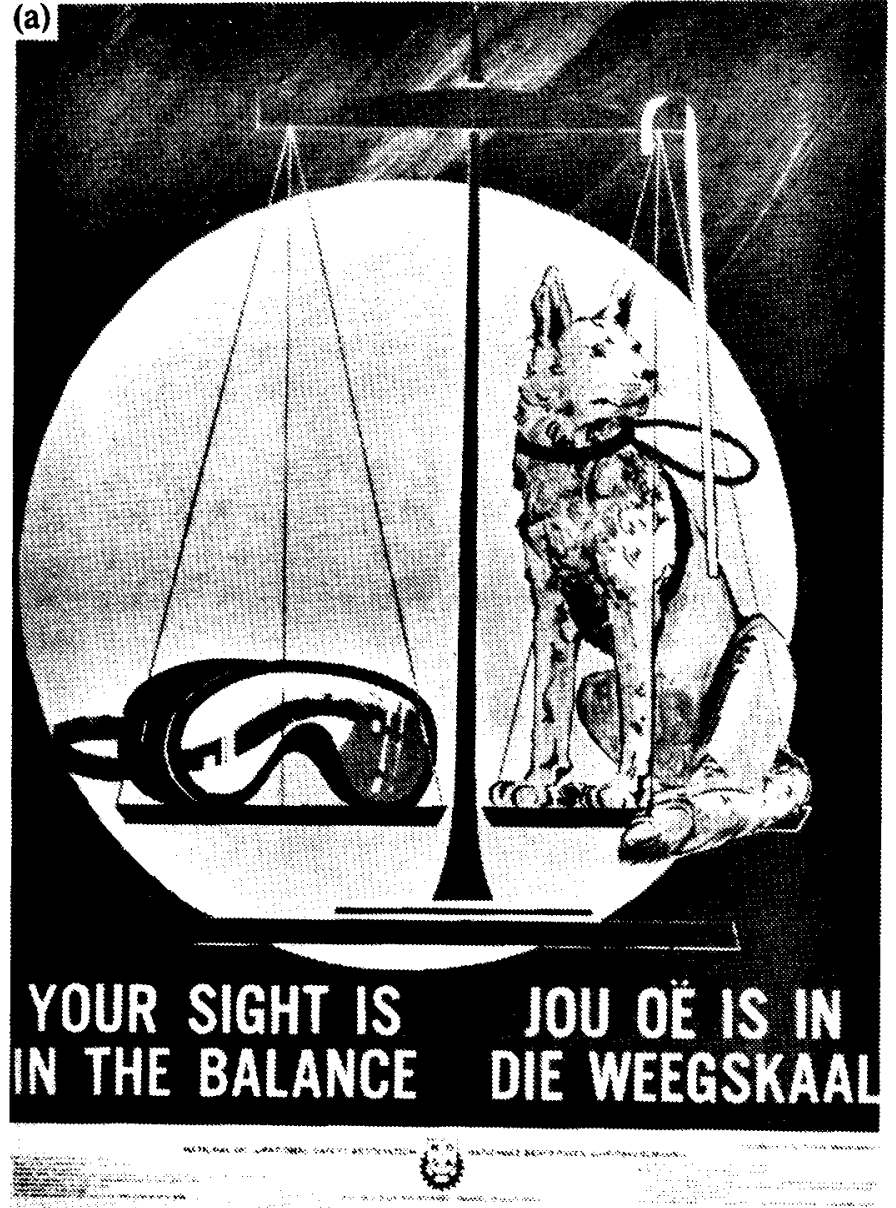

(b)

\section{Protect Yourself Beskerm Uself}

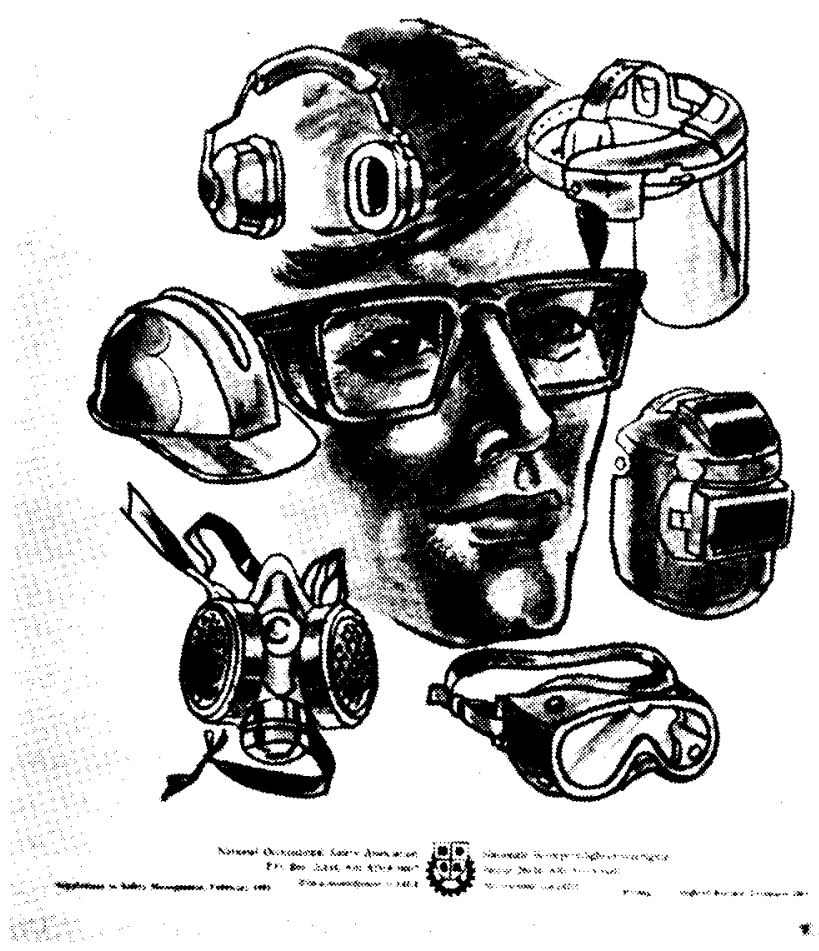

Figure 1 Showing two examples of existing (NOSA) safety posters: (a) The need to protect eyesight, (b) General protective equipment use

Table 2 Showing results of the pre-experimental survey of management (shopfloor and executive) and supervisory grades' dispostion towards safety measures in the workplace, $(N=14)$

\begin{tabular}{|c|c|c|}
\hline \multirow[b]{2}{*}{ Question } & \multicolumn{2}{|c|}{ Response } \\
\hline & Yes & No \\
\hline$(1-3)$ Biographical data & - & - \\
\hline $\begin{array}{l}\text { (4) Time spent on safety matters is time wasted. } \\
\text { Do you agree? }\end{array}$ & nil & 14 \\
\hline $\begin{array}{l}\text { (5) Most shopfloor workers comply with shopfloor } \\
\text { safety measures. Do you agree? }\end{array}$ & 1 & 13 \\
\hline $\begin{array}{l}\text { (6) Shopfloor safety measures and practices can be } \\
\text { improved. Do you agree? }\end{array}$ & 13 & 1 \\
\hline $\begin{array}{l}\text { (7) The use of visual aids and reminders would } \\
\text { benifit existing safety measures. Do you agree? }\end{array}$ & 13 & 1 \\
\hline $\begin{array}{l}\text { (8) Shopfloor safety is primarily the responsibility } \\
\text { of the shopfloor workers. Do you agree? }\end{array}$ & 3 & 11 \\
\hline
\end{tabular}

of the questions asked. However, later in this preliminary period these same respondents were interviewed on an informal basis about the same issues. The positive disposition displayed in the questionnaire survey was not reflected by the informal comments recorded, particularly at supervisory levels. The following quotations are illustrative of this contradictory position:

Respondent: Shop foreman.

'I've been in this game for 33 years now. I've got used to the noise.' (A response to the suggestion that supervisors could set an example by wearing ear protection when working in high-noise areas).

Respondent: Shop manager.

'We give the workers protective clothing . . If they won't wear it what can we do?'

Respondent: Shop foreman.

'If the workers bugger up my machines I kick their arses for them. If they injure themselves I do the same'.

Respondent: Shop foreman.

'The workers are given gloves to wear but they just don't wear them. I don't know why. If they get hurt then I feel that it is just their problem.'

Content analysis of these statements indicated that both managers and supervisors largely viewed their own role in the promotion and maintenance of safety practices as being limited to an instructional one; the determinants of unsafe activity were largely attributed to a mysterious inevitability over which they had no control.

\section{Preparation of experimental safety posters}

Paying close attention to the impressionistic comments of shopfloor workers towards existing poster material and with due regard to the wealth of information in psychological, ergonomics, and safety literature regarding the perception and interpretation of international safety symbols (Dreyfus, 1972; Stillerman, 1976; Anon, 1979 and Anon, 1981), a number of draft posters were sketched for each of the three safety phenomena (see Table 1). Effort was made to keep each sketch artistically simple and to concentrate on presenting the 
undamental elements of each target safety phenomenon. Thus for incidents involving the use of grindstones the essential iactors arising from the initial interviews with shopfloor workers were the grindstones, goggles, and eyes.

These initial sketches were then shown to individual shoploor workers who were selected at random from the populaions most at risk to each safety situation. Each respondent was requested, via a translator, to rank the sketches relating o each of the three target phenomena in order of significance and meaning in terms of instructional value about the right hing to do in each case. The leading designs were then professionally drawn up by graphics specialists into full poster format. The final designs are shown in Figure 2.

(a)

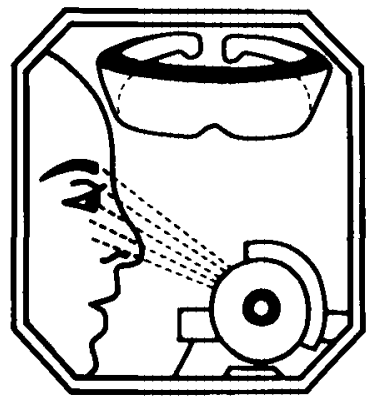

(b)

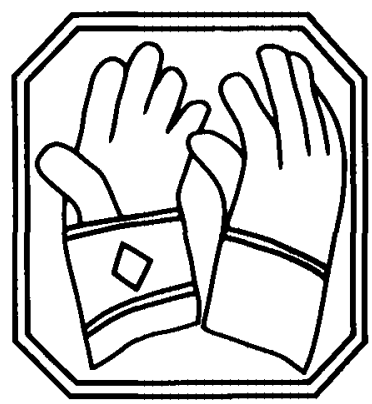

(c)

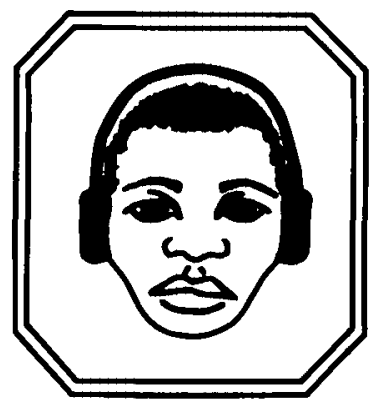

Figure 2 Showing the final designs for experimental safety posters: (a) The need to wear protective goggles, (b) The need to wear protective gloves, (c) The need to wear protective ear muffs

These posters were then printed and used as experimental safety propaganda material in the workshops under investigation. Care was taken to position the experimental posters in prominant positions at the workstations to be monitored. No other safety instruction or advice was given to either managers, supervisors, or workers.

\section{Experimental hypothesis}

The introduction of experimental safety propaganda will have the effect of reducing the number of observed unsafe incidents related to the target phenomena to below that found in a control period but these levels will rise again following the withdrawal of the experimental propaganda material.

\section{Data collection}

A repeated measures observational design was conducted over three four-week periods - a control, an experimental, and a post-experimental period. These periods are set out in Table 3. The dependent variable was thus the number of unsafe acts observed per observation hour. The independent variable was the experimental safety posters. A susidiary dependent variable is the degree of support given to safety procedures by managerial and supervisory grades.

Table 3 Showing details of the experimental design

\begin{tabular}{ll}
\hline Time Period & Experimental procedure \\
\hline Control period & $\begin{array}{l}\text { Existing safety behaviour is observed and } \\
\text { recorded }\end{array}$ \\
Experimental period & $\begin{array}{l}\text { Shopfloor workers exposed to experimental } \\
\text { safety propaganda material. Safety be- } \\
\text { haviour is observed and recorded } \\
\text { Experimental safety propaganda material is } \\
\text { period }\end{array}$ \\
& $\begin{array}{l}\text { withdrawn. Safety behaviour is observed } \\
\text { and recorded }\end{array}$ \\
\hline
\end{tabular}

The observational procedure was shaped by the diverse nature of the target phenomena. Certain jobs (e.g. riveting) are conducted with the operator remaining at one permanent, fixed workstation. Other target phenomena (e.g. use of grindstones) were observable at fixed points in the workshops but used only infrequently by various members of the workforce. A pseudo-randomized observational schedule was necessary to sample these different situations. The observation schedule covered all three of the four-week periods. A variety of non-safety related tasks (e.g. inspection and stock control), around the factory premises provided cover for the experimental observations.

The questionnaire survey conducted in the pre-experimental period to establish managerial and supervisory disposition towards safety was repeated following the end of the postexperimental period in order to record any changes in formally expressed disposition which may have arisen as a result of the safety propaganda campaign.

\section{Results}

The questionnaire

Respondents completed the questionnaire in exactly the same way as they had done during the preliminary investigation some four months previously. There is thus no change from Table 2. No further statistical analysis was conducted on these data.

\section{The observations}

Results set out in Table 4 were obtained from observational monitoring of the behavioural effect of safety propaganda related to the three target phenomena, viz. non-use of goggles, gloves, and ear muffs. The data are expressed as units of observed unsafe incidents per hour of observation time. Fluctuations in numbers of workers per workshop were monitored and were found to be negligable for the purposes of this study. Data are displayed on a phenomenon/workshop basis.

A Page's $L$ non-parametric trend test (Page, 1963) showed $\chi_{L}^{2}=1,786 ; P=0,09$.

The data recorded in Table 4 are re-expressed in Table 5 as ratios using the control period as unity. 
Table 4 Showing the number of unsafe acts recorded per hour of observation time as a function of target phenomena and workshop location

\begin{tabular}{lcccc}
\hline & \multicolumn{4}{c}{ Experimental period } \\
$\begin{array}{lcrcr}\text { Target } \\
\text { phenomena }\end{array}$ & $\begin{array}{c}\text { Work- } \\
\text { shop }\end{array}$ & Control & Experimental & $\begin{array}{c}\text { Post- } \\
\text { experimental }\end{array}$ \\
\hline Goggles & $\mathrm{A}$ & $\mathbf{8 , 3 3}$ & $\mathbf{6 , 3 3}$ & 5,20 \\
& $\mathrm{~B}$ & 1,00 & 1,07 & 0,96 \\
& $\mathrm{C}$ & 2,13 & 0,87 & 0,96 \\
Gloves & $\mathrm{A}$ & 33,67 & 18,00 & 20,00 \\
& $\mathrm{D}$ & $\mathbf{8 3 , 0 0}$ & $\mathbf{8 3 , 0 0}$ & 83,20 \\
Ear muffs & $\mathrm{A}$ & $\mathbf{6 , 3 3}$ & 7,33 & 14,00 \\
& $\mathrm{E}$ & 33,67 & 16,00 & 25,60 \\
\hline
\end{tabular}

Table 5 Showing unsafe acts recorded per hour of observation time expressed as ratios of control period figures for target phenomena and workshop location.

Experimental period

\begin{tabular}{lcccc}
$\begin{array}{l}\text { Target } \\
\text { phenomenon }\end{array}$ & $\begin{array}{c}\text { Work- } \\
\text { shop }\end{array}$ & Control & Experimental & $\begin{array}{c}\text { Post- } \\
\text { experimental }\end{array}$ \\
\hline Goggles & A & 1,00 & 0,76 & 0,62 \\
& B & 1,00 & 1,07 & 0,96 \\
Gloves & C & 1,00 & 0,41 & 0,45 \\
& A & 1,00 & 0,53 & 0,59 \\
Ear muffs & D & 1,00 & 1,00 & 1,00 \\
& A & 1,00 & 1,16 & 2,21 \\
& E & 1,00 & 0,46 & 0,76 \\
\hline
\end{tabular}

\section{Discussion of results}

To take the follow-up questionnaire aspect first, it should not be surprising to find no shift in respondents' manifest position of a strong positive commitment to safety and safety propaganda. However the apparent ambivalence between manifest statement and observable action, particularly on the part of supervisory grades, has much influence on the results of the observational study.

The observation results indicate a moderate trend in favour of the experimental hypothesis. For four of the seven targets the introduction of the experimental safety propaganda was followed by a prominant reduction in the number of unsafe acts observed. This reduction remained substantial even during the post-experimental period, though towards the end of this last four-week period the rate of unsafe acts observed was beginning to increase to the level recorded during the control period, suggesting that the awareness and concern generated by the poster campaign had finally ebbed.

The pattern of changes in observed unsafe acts is best seen in Table 5.

Of the three target phenomena which did not show reduction two remained constant across the experimental periods (non-use of goggles in workshop B and non-use of gloves in workshop D) while the third (non-use of ear muffs in workshop A) increased twofold.

No clear associations emerged between rate of unsafe act, workshop, or nature and frequency of use of workstations.

Workshop A for example shows substantial reductions in the non-use of goggles and gloves but provides a substantial increase (twofold) in the non-use of ear muffs. The latter occurrence is in part attributable to the flamboyant behaviour on the part of the shop supervisors, who themselves refused to wear ear protection or to enforce its wearing by others, and in part to the comparative mobility of workers around the workshop. The need to use goggles and gloves to perform specific tasks was recognized by all in this workshop (though unsafe acts were still in evidence) but the insidious hazard of high levels of continuous noise was largely not recognized despite the positioning of experimental posters at strategic high-noise locations.

In contrast workers in workshop $\mathrm{E}$ attended more static workstations with high levels of noise generated as an integral part of their primary task performance, (riveting). The nonuse of ear muffs was halved by the prominent positioning of experimental posters.

Similarly the induced reduction in non-use of gloves in workshop A contrasted with the apparent indifference to the experimental propaganda recorded in workshop D. Again this difference may be attributed to the nature of the task characteristics. The higher degree of manual dexterity required for most tasks in workshop D was not facilitated by the type of protective gloves provided. Non-use of gloves in this instance was not a safety choice so much as a task performance necessity. Safety propaganda cannot combat the unergonomic design of essential equipment.

Lastly the constant levels of non-use of goggles in workshop $B$ contrast with the substantial reductions found in workshops $A$ and $C$. This is in part attributable to the relative infrequent use of the grindstones in workshop B and in part to their most prominent users being the workshop supervisors who refused to use the goggles provided.

This apparent ambivalence between formal commitment to safety and observable unconcerned, often obstructive, behaviour is clearly of major concern above and beyond its effects upon safety propaganda impact. There is clearly much scope for further study into its determinants. Psychology is of course rich in theoretical constructs devised for the explanation of such disparate manifestations. However, an important feature of this situation is the genuine lack of awareness on the part of supervisory staff of both the nature of safety hazards and their own role in the promotion of safe behaviour. At the very least this points to an immediate training need (at all levels of the work-force) and may indicate a fundamental psychological problem.

\section{General discussion}

The study demonstrates that through the application of some basic exploration and evaluation techniques from the human sciences the meaning of safety posters can be increased from zero to significance. Indeed the results show that provided safety propaganda posters are constructed in a way which emphasizes the relevance of unsafe phenomena to those who are most at risk, their use will lead to the promotion of safe actions. However, where there is a general nonrealization of a hazard (e.g. the insidious nature of noise), and/or where there are unsupportive managerial or supervisory dispositions, and/or where there is evidence of the unergonomic nature of safety equipment, the likelihood of safety propaganda producing a substantial change in safety behaviour will be negligible.

An investment of both time and effort in the observance of safety procedures is necessary for the elimination of unsafe acts in the workplace. So too is a broader understanding of the relationship between unsafe behaviour and the supportive factors of task structure and procedure, equipment appropri- 
ateness and the general operating environment, (Surry, 1969; Adams, Barlow \& Hiddlestone, 1981; Edwards, 1981; Robinson, 1982 and Fisher, 1983).

\section{Conclusion}

The study thus adds support to the view that safety posters can be effective, but cannot be regarded as alternatives to devising safety procedures and promoting safety awareness in a broader organizational context, (Sell, 1977). They may however serve as reminders to reinforce other methods, (Lander \& Sell, 1960).

\section{References}

Anon 1979. Standardised workplace safety signs. Appl. Ergon., vol. 10, (3), 190-191.

Anon 1981. Standard safety signs. Appl. Ergon., vol. 12, (1), $61-62$.

Adams, N.L., Barlow A. and Hiddlestone J. 1981. Obtaining ergonomics information about industrial injuries - a five year analysis. Appl. Ergon., vol. 12, (2), 71-81.

Department of Manpower. 1984. Report of the Director General for the year ended 31 December 1983. Government printer. Pretoria.

Dreyfus, H. 1972. Symbol sourcebook. New York: McGraw-Hill.

Edwards, M. 1981. The design of an accident investigation procedure. Appl. Ergon., vol. 12, (2), 111-115.

Fisher, J. 1983. Reducing the frequency and severity of industrial accidents - an ergonomics approach. S. Afr. J. Labour Relat., vol. 7, (4), 4-17.

Lander, S. \& Sell, R. 1960. An experiment on the effect of specially designed safety posters. Occup. Psychol., vol. 34, $153-169$.

National Occupational Safety Association (NOSA). 1979. The $M B O$ system leading to a 5 star rating. NOSA. Pretoria.

Page, E.B. 1963. Ordered hypothesis for multiple treatments; a significance test for linear ranks. Am. Stat. Assoc. J., $216-230$.

Robinson G.H. 1982. Accidents and sociotechnical systems; principles for design. Accid. Anal. Prev., vol. 14, (2), $121-130$.

Siegal, S. 1956. Nonparametric statistics for the behavioural sciences. Kogakusha, Tokyo: McGraw-Hill.

Sell, R.G. 1977. What does safety propaganda do for safety? A review. Appl. Ergon., vol. 8, (4), $203-214$.

Stillerman, E.D. 1976. Comprehension of ISO industrial safety signs among white, black literate and black illiterate workers. National Institute for Personnel Research. Johannesburg.

Surry, J. 1969. Industrial accident research. A human engineering appraisal. Ontario Ministry of Labor. Toronto.

Winter, W. 1963. The perception of safety posters by bantu industrial workers. Psychol. Afr., vol. 10, 127-135. 